\title{
Confirmação de infecção por Brucella abortus em um rebanho bovino certificado livre em Minas Gerais: relato de caso
}

\author{
[Brucella abortus infection in an officially brucellosis-free bovine herd in \\ Minas Gerais State - Brazil: a case report] \\ P.M. Soares Filho ${ }^{1}$, R.P.B. Wanderley ${ }^{2}$, G.C. Faria ${ }^{1}$, A.G. Penna ${ }^{1}$, D.B.C.L. Ribeiro ${ }^{3}$, \\ R.A. Assis ${ }^{1}$, R.C. Leite $^{5}$, A. A. Fonseca Junior ${ }^{1}$, A.C.C.L. Ribeiro ${ }^{4}$ \\ ${ }^{1}$ Ministério de Agricultura, Pecuária e Abastecimento - Mapa - Pedro Leopoldo, MG \\ ${ }^{2}$ Aluno de pós-graduação - Escola de Veterinária - Universidade Federal de Minas Gerais - Belo Horizonte, MG \\ ${ }^{3}$ Aluno de Graduação - Escola de Veterinária - Universidade Federal de Lavras - Lavras, MG \\ ${ }^{4}$ Embrapa Gado de Leite - Coronel Pacheco, MG \\ ${ }^{5}$ Escola de Veterinária - Universidade Federal de Minas Gerais - Belo Horizonte, MG
}

\begin{abstract}
RESUMO
Relata-se a ocorrência de um surto de brucelose em um rebanho de aproximadamente 1000 animais, livre da doença há 18 anos, certificado pelo Ministério da Agricultura, Pecuária e Abastecimento desde 2006. Dois animais reagiram aos testes sorológicos de diagnóstico por ocasião dos procedimentos de recertificação em 2008. Após o sacrifício deles, Brucella abortus, biovariedade 1, amostra não vacinal, foi isolada e identificada por meio de provas bioquímicas e de biologia molecular (PCR AMOS). A origem do agente no rebanho é de difícil determinação. No entanto, a adoção de procedimentos preconizados pelo Programa Nacional de Controle e Erradicação da Brucelose permitiu evitar a disseminação da enfermidade. Ocorrências como essas, em que rebanhos livres foram infectados após anos sem a ocorrência de brucelose, nunca haviam sido relatadas no Brasil.
\end{abstract}

Palavras-chave: brucelose, bovino, rebanho livre, isolamento

\begin{abstract}
A Brucellosis outbreak is reported in a bovine herd free from the disease for over 18 years, officially free since 2006. One heifer and one cow tested positive in serological tests for the 2008 annual recertification in a herd of almost 1000 animals. Isolation and identification by biochemical tests and molecular biology (AMOS PCR) confirmed the infection by a Brucella abortus biovar 1 field strain. It wasn't possible to find the source of the infection. However, adoption of standard procedures prescribed by the Brazilian National Brucellosis and Tuberculosis Control and Eradication Program hindered the spread of the disease. This is the first report of a Brucella infection in an officially Brucellosis-free bovine herd in Brazil.
\end{abstract}

Keeywords: brucellosis, bovine, free herd, isolation

\section{INTRODUÇÃO}

A brucelose é uma doença infecciosa causada por bactérias do gênero Brucella, com dez espécies reconhecidas, a qual afeta grande número de mamíferos. Cada espécie tem seu hospedeiro preferencial, sendo a Brucella abortus a de maior importância no Brasil pela sua prevalência nos bovinos.
No país, essa doença é conhecida desde a primeira metade do século 20, mas só em 2001, o Ministério da Agricultura, Pecuária e Abastecimento (Mapa) estabeleceu um Programa Nacional de Controle e Erradicação da Brucelose e da Tuberculose (PNCEBT), no qual são previstas medidas de certificação de propriedades livres ou monitoradas após uma

Recebido em 15 de abril de 2011

Aceito em 30 de maio de 2012

E-mail: paulo.soares@agricultura.gov.br 
sequência de testes diagnósticos padronizados (Brasil, 2006). A certificação de uma propriedade só é concedida pelo Mapa quando todas as fêmeas acima de 24 meses, vacinadas com B-19, e todos os machos acima de oito meses forem sorologicamente negativos em três exames sorológicos consecutivos.

O presente relato objetiva descrever a ocorrência de brucelose bovina em um rebanho em que foram encontrados animais reagentes à sorologia e em que a infecção foi confirmada por meio de isolamento e identificação do agente causal, em uma situação na qual o valor preditivo positivo dos testes diagnósticos era muito baixo por se tratar de um rebanho certificado livre da doença.

\section{CASUÍSTICA}

Esse rebanho era composto de, aproximadamente, 1000 animais HPB puros e mestiços Holandês/Zebu (H/Z) em vários graus de cruzamento. Os animais puros eram mantidos confinados, e os mestiços em regime de pasto com suplementação alimentar. A vacinação contra brucelose era feita nas bezerras entre três e oito meses de idade, desde 1976, com vacinas comerciais B-19. O rebanho era fechado desde 1980 e monitorado sorologicamente para brucelose desde 1990. Esse estado sanitário permitiu obter certificação de propriedade livre de brucelose em 2006 pelo Mapa.

Por ocasião dos exames para recertificação em 2008, dois animais, os de $n^{\circ} 2418$ e $n^{\circ} 6075$, reagiram ao teste do antígeno acidificado tamponado (AAT) dentre 600 animais testados, fêmeas acima de 24 meses e machos acima de oito. O animal 2418 era uma vaca mestiça $7 / 8$ $\mathrm{H} / \mathrm{Z}$, de quatro anos de idade, primípara (parto 01/11/2006), criada a pasto, que à época encontrava-se seca. $O$ animal 6075 era uma novilha mestiça 15/16 H/Z, de dois anos de idade, no quarto mês de gestação, criada nas mesmas condições anteriores. Os soros desses animais foram submetidos ao teste confirmatório, 2-mercaptoetanol (2-ME) (Brasil, 2006) e, posteriormente, à fixação de complemento (FC) (Alton et al., 1988) e à polarização fluorescente (FPA) (Nielsen et al., 1996), sendo utilizado o "Brucella abortus Antibody Test Kit", produzido por Diachemix, USA, e o equipamento de leitura de polarização fluorescente modelo Sentry 100® (Diachemix, USA). Uma vez reagentes ao teste confirmatório do 2-ME, os animais foram sacrificados na propriedade, conforme recomenda o PNCEBT. Linfonodos supramamários, ilíaco interno, retrofaríngeo, préescapular e fragmento da glândula mamária foram coletados assepticamente e encaminhados ao Laboratório Nacional Agropecuário de Minas Gerais (Lanagro-MG) para isolamento e identificação de Brucella.

Após o sacrifício dos animais reagentes, foram realizados três testes de triagem pelo AAT em todas as fêmeas acima de 24 meses e em todos os machos restantes no rebanho acima de oito, em intervalos de 30 dias, além dos dois outros testes consecutivos (AAT), realizados com intervalos de 30 a 90 dias, prescritos pelo PNCEBT para recertificação de uma propriedade livre infectada (Brasil, 2006).

Para o isolamento, as amostras foram processadas de acordo com Alton et al. (1988). Inicialmente, fez-se a maceração de um fragmento de aproximadamente $2 \mathrm{~cm}(10 \mathrm{~g})$ de cada amostra coletada, com volume de salina correspondente a duas vezes o peso do material. Após, uma alíquota do material macerado foi inoculada na superfície de duas placas de ágar triptose (Difco ${ }^{\circledR} / \mathrm{BD}$, EUA), uma com $5 \%$ de soro e outra com $5 \%$ de soro e suplemento seletivo de Farrell (OXOID LTDA., Inglaterra). As placas foram incubadas a $37^{\circ} \mathrm{C}$, em ambiente com $5 \%$ de $\mathrm{CO}_{2}$ por 14 dias, e examinadas um dia após a inoculação e aos quatro, sete e 14 dias. Todas as colônias típicas que cresceram neste período, a partir do quarto dia, foram colhidas e submetidas às provas de identificação.

Para identificação das colônias suspeitas, foram realizadas coloração pelo Gram, provas de fermentação da glicose e da lactose, produção de indol, motilidade a $37^{\circ} \mathrm{C}$ e a $22^{\circ} \mathrm{C}$, redução do nitrato, catalase, oxidase, urease, utilização do citrato, hemólise e liquefação da gelatina. Para determinação da espécie e determinação da biovaridade, foram feitas provas de dissociação, de necessidade de soro e de $\mathrm{CO}_{2}$, de produção de gás sulfídrico, de crescimento na presença de tionina e na presença de fuccina, de aglutinação frente a soros monoespecíficos anti-A e anti-M (Alton et al., 1988). Adicionalmente, colônias características foram submetidas à prova de reação em cadeia de polimerase (PCR), com o intuito de amplificar fragmentos gênicos capazes 
de identificar B. abortus, biovariedades 1,2 e 4; B. melitensis, biovariedades 1,2 e $3 ; B$. ovis e $B$. suis, biovariedade 1 (PCR AMOS) (Bricker e Harlling, 1994).
Os resultados relativos às provas sorológicas dos animais 2418 e 6075 estão demonstrados na Tab. 1. Conforme verificado, ambos reagiram em todas as provas empregadas.

Tabela 1. Resultados das provas sorológicas aplicadas nos soros dos animais 2418 e 6075 para detecção de aglutininas anti-Brucella

\begin{tabular}{clccc}
\hline Animal & AAT & $\begin{array}{c}\text { SAL/2-ME } \\
\text { (títulos) }\end{array}$ & $\begin{array}{c}\text { FC } \\
\text { (títulos) }\end{array}$ & $\begin{array}{c}\text { FPA } \\
\text { (unidades de } \\
\text { milipolarização) }\end{array}$ \\
\hline 2418 & Reagente & $200 / 200$ & 64 & 213,8 \\
6075 & Reagente & $100 \mathrm{I} / 100 \mathrm{I}$ & 8 & 201,02 \\
\hline AAT - antígeno
\end{tabular}

AAT - antígeno acidificado tamponado, SAL/2-ME - soroaglutinação lenta/2-mercaptoetanol, FC - fixação de complemento, FPA - polarização fluorescente.

Nenhum outro animal reagente foi encontrado nas demais provas sorológicas realizadas.

Houve o isolamento de colônias típicas de Brucella a partir de amostras do animal 2418. Pela PCR AMOS, os isolados foram classificados como B. abortus. Os testes de identificação tradicionais permitiram classificálos como Brucella abortus, biovariedade 1, a qual necessitou $\mathrm{CO}_{2}$ para o seu desenvolvimento.

Com base nos resultados sorológicos e bacteriológicos, firmou-se a ocorrência de brucelose no rebanho avaliado.

\section{DISCUSSÃO}

Ocorrências como estas, em que rebanhos livres foram infectados após anos sem a ocorrência de brucelose, apesar de nunca terem sido relatadas no Brasil, já o foram em outros países (Baker e Faull, 1967; Trueman et al., 1979; Lapraik, 1982; Ryan, 1992; Meat..., 2009). Em todos esses casos, houve uma detalhada investigação sobre a real infecção dos rebanhos estudados, dado o avançado estágio do controle da doença em que se encontravam.

Da mesma forma, houve a necessidade de aprofundamento na investigação dos achados aqui relatados, a despeito dos resultados obtidos a partir dos testes sorológicos. Por se tratar de um rebanho livre de brucelose há vários anos, oficialmente certificado pelo Mapa, o valor preditivo positivo dos testes era muito baixo, próximo de zero, independentemente da sua especificidade (Brasil, 2006).
Apesar de ainda pouco utilizadas no Brasil, onde não têm seus respectivos pontos de corte devidamente estabelecidos pelo PNCEBT, os resultados da FC e da FPA são, de modo geral, compatíveis com diagnóstico positivo de acordo com Alton et al. (1988) e Nielsen et al. (1996). Os altos títulos obtidos na SAL/2-ME e na FC e os valores de milipolarização demonstraram concordância entre os resultados encontrados nas diferentes provas.

O isolamento de Brucella abortus obtido a partir de amostras do animal 2418 permitiu firmar, conclusivamente, o diagnóstico do rebanho. Levando-se em consideração os resultados da prova de requerimento de $\mathrm{CO}_{2}$, pode-se afirmar que as bactérias isoladas não constituíam amostra vacinal B-19, dado que ela não requer gás carbônico para o seu desenvolvimento (Alton et al., 1988).

A origem do agente no rebanho é de difícil determinação, no entanto pode-se levantar a hipótese de que animais silvestres seriam a fonte de transmissão. Nessa propriedade, é comum encontrar rebanhos de capivaras (Hidrochaeris hidrochaeris) ao longo dos cursos de água e nas plantações de milho e cana. Lord e Flores (1983) isolaram $B$. abortus de capivaras que conviviam com bovinos, na Venezuela, o que torna esse animal um possível reservatório. Cervídeos e outros animais silvestres, embora em menor número, também podem estar presentes. No entanto, Gonçalves et al. (2009) argumentam a necessidade de estudos mais aprofundados sobre os cervídeos silvestres serem efetivamente reservatório da doença. 
Outra hipótese seria a contaminação por meio de rebanhos vizinhos, já que a doença é endêmica na região, onde a prevalência de rebanhos foi estimada em 6,5\% por Gonçalves et al. (2009), e este tipo de ocorrência já foi relatado em outros países por Baker e Faull (1967); Trueman et al. (1979); Lapraik (1982) e Meat... (2009). Além disso, Kellar et al. (1976) concluíram que rebanhos infectados, distantes até $3 \mathrm{~km}$, aproximadamente, de rebanhos livres, ainda constituíam fator de risco. Entretanto, a possibilidade de contato entre rebanhos, neste caso particular, pareceu ser muito pouco provável, uma vez que grande parte das divisas da fazenda é constituída por mata fechada e cursos d'água que não permitem a passagem de animais, e o restante por cercas bem conservadas.

Independentemente da origem, somente os animais 2418 e 6075 se infectaram. O tempestivo sacrifício deles, antes que viessem a parir ou abortar, parece ter contribuído decisivamente para evitar a disseminação da doença.

\section{CONCLUSÃO}

Pode-se concluir que, mesmo em condições de baixo valor preditivo positivo, condição encontrada em rebanhos livres, é possível surgir animais reagentes aos testes sorológicos para a brucelose infectados por Brucella de origem desconhecida, constituindo-se risco para disseminação da doença dentro do próprio rebanho e para rebanhos vizinhos. No entanto, sua eliminação tempestiva evita a disseminação a outros animais.

\section{REFERÊNCIAS}

ALTON, J.J.; JONES, L.M.; ANGUS, R.D.; VERGER, J.M. Techniques for the brucellosis laboratory. Paris: INRA, Paris, 1988. 190p.

BAKER, J.R.; FAULL, W.B. Brucellosis in a large dairy herd. Vet. Rec., v.81, p.560-564, 1967.
BRASIL. Ministério da Agricultura, Pecuária e Abastecimento. Programa Nacional de Controle $e$ Erradicação da Brucelose $e$ da Tuberculose Animal. 2006. Disponível em: http://www.agricultura.gov.br/arq_editor/file/Ani amal/programa\%20nacional\%20sanidade\%20bru celose/Manual\%20do\%20PNCEBT\%20\%20Original.pdf. Acesso em: 17 mai. 2012.

BRICKER, B.T.; HALLING, S.M. Differentiation of Brucella abortus bv. 1, 2 and 4, Brucella melitensis, Brucella ovis, and Brucella suis bv. 1 by PCR. J. Clin. Microbiol., v.32, p.2660-2666, 1994.

GONÇALVES, V.S.P.; DELPHINO, M.K.V.C.; DIAS, R.A. et al. Situação epidemiológica de brucelose bovina no Estado de Minas Gerais. Arq. Bras. Med. Vet. Zootec., v.61, supl. 1, p.3545, 2009.

KELLAR, J.; MARRA, R.; MARTIN, W. Brucellosis in Ontario: a case control study. Can. J. Comp. Med., v.40, p.119-128, 1976.

LAPRAIK, R.D. Latent bovine brucellosis. Vet. Rec., v.111, p.578-579, 1982.

LORD, V.R.; FLORES, R.C. Brucella spp. from capybara (Hidrochaeris hidrochaeris) in Venezuela: serologic studies and metabolic characterization of isolates. J. Wildl. Dis., v.19, p.308-314, 1983.

MEAT Trade News Daily. USA - Second cow tests positive with brucellosis. 2009. Disponível em: <http://www.meattradenewsdaily.co.uk>. Acesso em: 15 dez. 2009.

NIELSEN, K.; GALL, D.; JOLLEY, M. et al. A homogeneous fluorescence polarization assay for detection of antibody to Brucella abortus. J. Immunol. Methods. v.195, p.161-168, 1996.

RYAN, T.J. Bovine brucellosis eradication - the end game. Surveillance, v.19, p.23-24, 1992.

TRUEMAN, K.F.; THOMAS, A.D.; SPINKS, G.A. Observations on single brucellosis reactors in large herds. Aust. Vet. J., v.55, p.175-179, 1979. 